\title{
Knowledge and Risk Behavior on Hepatitis C Virus Infection Among Laboratory Technicians in A Selected Army Medical Unit
}

\author{
*AKMF Hossain ${ }^{1}$, MM Rahman²
}

\begin{abstract}
Background: Hepatitis C virus (HCV) is a new virus identified in the year 1989. Regarding the morbidity \& mortality and also for disease burden HCV infection is now an important disease phenomenon worldwide especially among the health care professionals. Laboratory technicians are at increased risk for acquiring blood-borne infections as they have to collect blood samples to find out the disease pathology. The aim of this study is to assess the knowledge and risk behavior on HCV infection among laboratory technicians in a selected army medical unit.
\end{abstract}

Methods: A descriptive cross sectional study was conducted among laboratory technician in a selected army medical unit from 01September 2015 to 31 December 2016. Total 105 participants were interviewed by pretested structured questionnaire.

Results: This study explored that $44.8 \%$ respondents were in between $31-40$ years and $63.8 \%$ were educated up to HSC level. All the respondents had overall knowledge about the cause, high risk group and prevention of HCV infection and $20.95 \%$ were not aware that water did not transmit HCV infection, $55.24 \%$ had no information of vaccination for prevention of HCV infection. This knowledge was gained by majority (62\%) of participants from their existing course curriculum. Use of disposable syringe, sterilize instruments, practice of recapping after using needles and their proper disposal were found among all of the respondents and $61 \%$ did not habit to use gloves during sample collection due to negligence and lack of time. This study showed that there is an association between level of education and risk behavior (use of gloves) $(\mathrm{P}<.005)$.

Conclusion: Adequate program on updating knowledge, strict use of gloves, sterile instrument during sample collection will be helpful in minimizing transmission of HCV infection.

Key Words: Hepatitis C virus, Risk behavior, Laboratory technicians.

\section{Inroduction}

Hepatitis $\mathrm{C}$ virus $(\mathrm{HCV})$ is identified as a new virus in1989. ${ }^{1}$ Screening assay for antibody to HCV became available late in 1990 and their use has subsequently become widespread. The genomes of hepatitis $\mathrm{C}$ virus display significant sequence heterogeneity. Six types (1 to 6) and many subtypes have been identified. ${ }^{2}$ Presence of various genotypes has epidemiologic and therapeutic implications. Persons who develops acute HCV infection rarely recover completely; more than $80 \%$ of them remain
HCV infected eventually leading to chronic hepatitis and or hepatocellular carcinoma. The incidence of $\mathrm{HCV}$ on a global scale is not well known, because acute infection is generally asymptomatic. ${ }^{3}$ There is no vaccine against this virus till today. WHO estimates that about $3 \%$ of the world's population has been infected with $\mathrm{HCV}$ and that there are more than 170 million chronic carriers who are at risk of developing liver cirrhosis and/or liver cancer. ${ }^{4}$ Worldwide HCV infects nearly 200 million people

$1 *$ Lt Col AKM Farhad Hossain, AFMI, Dhaka Cantonment, e-mail: farhad100884@gmail.com

${ }^{2}$ Prof. Md Mahfuzur Rahman, Department of community medicine, Anwer khan Modern Medical College

*Corresponding Author

Date of submission: 12.07.2018 Date of acceptance: 06.10.2018

AKMMC J 2019; 10(1) : 38-42 
and 4 million in USA. ${ }^{5}$ A survey was conducted in California showed prevalence of up to $40 \%$ among prison inmates. $62 \%$ of subjects diagnosed with hepatitis $\mathrm{C}$ have previously been in jail. ${ }^{7}$ Prevalence is higher in some countries in Africa and Asia. Egypt has the highest sero prevalence for $\mathrm{HCV}$, up to $20 \%$ in some areas. There is a hypothesis that the high prevalence is linked to a now-discontinued mass-treatment campaign for schistosomiasis, which is endemic in that country. ${ }^{8}$

There is no population based data on HCV prevalence in Bangladesh. In 1993, Khan et al have reported zero prevalence of $\mathrm{HCV}$ among blood donors in Bangladesh. ${ }^{9}$ However, this was contradicted when Akbar et al reported that about 5\% apparently healthy subjects of Bangladesh were harboring HCV RNA. ${ }^{10}$ Recently a study conducted in rural Bangladesh has shown that $0.5 \%$ apparently healthy subjects were infected with HCV.11 The major known routes of transmission are parenteral, intravenous drug abuse, contaminated injection devices and receipt of unscreened blood or blood products. ${ }^{12}$

Health care workers who have occupational exposure to blood are at increased risk for acquiring blood-borne infections. The level of risk depends on the number of patients with that infection in the health care facility and the precautions the health care workers observe while dealing these patients. There are more than 20 blood-borne diseases, but those of primary significance to health care workers are hepatitis due to either the hepatitis B virus (HBV) or hepatitis C virus (HCV) and acquired immunodeficiency syndrome (AIDS) due to human immunodeficiency virus (HIV). ${ }^{13}$

Laboratory technicians are more vulnerable to infectious diseases as they have to collect blood samples, biopsy specimens and others to find out the pathology. As vital members of the health care team among the army personal, medical laboratory professionals play a critical role in collecting the information needed to give the best care to an ill or injured patient. So to kept reserve skilled manpower and also reduce the disease burden in armed forces, laboratory technicians must acquire the exact knowledge and risk behavior about HCV infection for safeguard themselves as well as others.
In Bangladesh no significant study has been done about the knowledge and risk behavior on HCV infection among laboratory technicians. The purpose of the study was to assess the knowledge and risk behavior on HCV infection among laboratory technicians and focused to address its prevention strategy. It will also help the policy maker to develop and implement effective programs to combat the situation for conserve the manpower both in peace and war time.

\section{Materials and Methods}

A descriptive cross sectional study was undertaken in selected army medical unit from 01 September 2015 to 31 December 2016. A group of 105 laboratory technicians were selected who were permanently posted and were grades into strata basing on their age, education and salary structure. Then purposive sampling method was used to select the participants to collect data and information. Confidentially was duly ensured to all participants and informed consent was obtained. Selfadministered structured questionnaire were used keeping focus on organizational supportive activities. Likert scale were re-categorized into three grade-point option for the purpose of data analysis regarding acquiring of knowledge. Focus group discussion was done among 25 of the participants in an organized place to collect the direct views and statements about the topics. The discussion was held by direct observing and interviewing the participants about the knowledge and risk behavior of $\mathrm{HCV}$ infection as well as of its prevention. After pretesting, the questionnaire was finalized and used for data collection. Level of significance assumed at $5 \%$ level $(\alpha=0.05)$. Ethical approval of the study was taken from the concerning authority. Before collection of data, an explanation was made to all respondents about the purpose of the study and the questionnaire. Data were analyzed with the help of SPSS windows program version 20 .

\section{RESULTS}

Around half of the respondents (44.8\%) age group were in between 31-40 years and the highest number 
of respondents (63.8\%) were educated up to HSC (TABLE-1). All of the respondents (100\%) knew the cause, high risk group and prevention of $\mathrm{HCV}$ infection, (47.61\%) of respondents were not aware that water did not transmit $\mathrm{HCV}$ infection and $55.24 \%$ of respondents were not aware of vaccination for prevention of $\mathrm{HCV}$ infection (TABLE-II ). Most of the respondents (62\%) opined course curriculum was the main source to know about HCV infection (TABLE-III). Use of disposable syringe and sterilize instruments, practice of recapping after using needle and syringe and proper disposal of used needles were found among all of the respondents and $61.0 \%$ of respondents did not habit of use of gloves during sample collection procedure (TABLE-IV). The association between level of education and risk behavior (use of gloves) was found statistically highly significant among the respondents $(\mathrm{P}, .005)$.

Focus group discussion was held among 25 of the participants in an organized place by direct observing and interviewing the participants about the knowledge and risk behavior of HCV infection as well as of its prevention. It was revealed that most of the participants were confident about HCV infection as the main source of infection and aware of the mode of transmission, risk group, risk behavior of HCV infection. Respondents opined the approaches on improvement of unsafe behavior by using gloves during sample collection, not sharing of needles and proper disposing of syringe.

Table-I: Distribution of respondents by sociodemographic characteristics $(n=105)$

\begin{tabular}{llcc}
\hline Character & Group & Frequency & Percentage \\
\hline Age in years & $20-30$ & 40 & $38.1 \%$ \\
& $31-40$ & 47 & $44.8 \%$ \\
& 40 & 18 & $17.1 \%$ \\
Educational level & SSC/equivalent & 32 & $30.5 \%$ \\
& HSC/equivalent & 67 & $63.8 \%$ \\
& Graduate and above & 6 & $5.7 \%$ \\
\hline
\end{tabular}

AKMF Hossain, MM Rahman

Table-II: Distribution of respondents knowledge on HCV infection $(n=105)$

\begin{tabular}{llll}
\hline Statements & $\begin{array}{l}\text { Strongly } \\
\text { Agree/Agree\% }\end{array}$ & Undecided\% & $\begin{array}{l}\text { Strongly } \\
\text { Disagree/ } \\
\text { Disagree }\end{array}$ \\
\hline $\begin{array}{l}\text { Virus is the main } \\
\text { cause }\end{array}$ & $105(100 \%)$ & - & - \\
Transmits by water & $22(20.95 \%)$ & $33(31.42 \%)$ & $50(47.61 \%)$ \\
$\begin{array}{l}\text { IV drug use is } \\
\text { important mode of } \\
\text { transmission }\end{array}$ & $103(98.1 \%)$ & $1(1 \%)$ & $1(1 \%)$ \\
$\begin{array}{l}\text { Main complication } \\
\text { is Cirrhosis of liver }\end{array}$ & $102(97.14 \%)$ & $3(2.86 \%)$ & - \\
$\begin{array}{l}\text { Laboratory } \\
\text { technicians are in } \\
\text { high risk group }\end{array}$ & $105(100 \%)$ & - & - \\
$\begin{array}{l}\text { HCV prevented by } \\
\text { avoiding sharing } \\
\text { needle }\end{array}$ & $105(100 \%)$ & - & - \\
$\begin{array}{l}\text { No vaccination for } \\
\text { HCV infection }\end{array}$ & $58(55.24 \%)$ & $41(39.04 \%)$ & $6(5.72 \%)$ \\
\hline
\end{tabular}

Table III: Distribution of respondents knowledge on source of information of $\mathrm{HCV}$ infection $(n=105)$.

\begin{tabular}{lcc}
\hline Source & Frequency & Percentage \\
\hline Course curriculum & 65 & $62 \%$ \\
Campaign program & 18 & $14.28 \%$ \\
Training & 10 & $10 \%$ \\
TV and print media & 12 & $11.42 \%$ \\
Total & $\mathbf{1 0 5}$ & $\mathbf{1 0 0 \%}$ \\
\hline
\end{tabular}

Table -IV: Distribution of respondents by information related to risk behavior $(n=105)$.

\begin{tabular}{lll}
\hline Particulars of risk behavior related information & Yes\% & No\% \\
\hline Use of gloves during sample collection & $41(39.0)$ & $64(61.0)$ \\
$\begin{array}{l}\text { Use of disposable syringe during } \\
\text { sample collection }\end{array}$ & $105(100)$ & - \\
$\begin{array}{l}\text { Use of sterilize instruments during } \\
\text { specimen collection }\end{array}$ & $105(100)$ & - \\
$\begin{array}{l}\text { Practice of recapping after using } \\
\text { needle and syringe }\end{array}$ & $105(100)$ & - \\
Proper disposal of used needles and & $105(100)-$ \\
\hline
\end{tabular}


Table-V : Distribution of respondents by association between educational status and risk behavior $(n=105)$.

\begin{tabular}{lllll}
\hline \multirow{2}{*}{$\begin{array}{l}\text { Education of the } \\
\text { respondents }\end{array}$} & \multicolumn{2}{c}{ Use of gloves } & Total & P \\
\hline SSC/equivalent & $26(24.8 \%)$ & $6(5.7 \%)$ & $32(30.4 \%)$ & \\
HSC/ equivalent & $9(8.6 \%)$ & $58(55.2 \%)$ & $67(63.8 \%)$ & $<0.005$ \\
$\begin{array}{l}\text { Graduate and } \\
\text { above }\end{array}$ & $6(5.7 \%)$ & - & $6(5.7 \%)$ & \\
Total & $41(39.0 \%)$ & $64(61.0 \%)$ & $105(100 \%)$ & \\
\hline
\end{tabular}

\section{Discussion}

This descriptive study focused on to assess the prevailing knowledge and risk behaviors on $\mathrm{HCV}$ infection and also to the socio-demographic characteristics and nature of motivational exposure. Respondents (44.8\%) were in between 31-40 years and $63.8 \%$ were educated up to HSC level. All of the respondents $(100 \%)$ knew that virus was the main cause of $\mathrm{HCV}$ infection and laboratory technicians and intravenous drug users were high risk group which were nearly correlated (about $87 \%$ of respondents) with the study done by Prasad L (2009). ${ }^{14}$ About 55.24\% respondents were not aware of vaccination for prevention of $\mathrm{HCV}$ infection. Hussain S, Patrick N, Shams R, et al. (2010) shown that $42 \%$ of respondents were unaware about vaccination on HCV infection. ${ }^{15}$ Knowledge on $\mathrm{HCV}$ infection by most of the respondents (62\%) acquired from existing course curriculum and a similar findings was found in the study Prasad L (2009). ${ }^{14}$ It was observed that use of disposable syringe, sterilize instruments, practice of recapping after using needle and syringe and proper disposal of used needles were found among 100\% respondents. However regarding the use of gloves it was not practiced during sample collection among $(61.0 \%)$ of respondents due to lack of time and negligence. Gurubacharya DL, KC Mathura, Karki DB et al. (2008) conducted a study which revealed that only $23 \%$ respondents were in the habit of using gloves. ${ }^{16}$ The association between the level of education and risk behavior (use of gloves) was found statistically highly significant among the respondents having education level HSC classes due to lack of time and negligence. In a study conducted by Prasad L (2009) revealed that there were no association between level of knowledge and risk behavior among the respondents due to that risk behavior is not only determined by the level of knowledge. ${ }^{14}$

It was revealed from the discussion in focus group on $\mathrm{HCV}$ virus infection that most of the participants were confident about $\mathrm{HCV}$ infection as the main source of infection. Moreover participants were aware of the mode of transmission, high risk health care professionals, unsafe and risk behavior of HCV infection. The respondents opined the approaches on improvement of unsafe behavior by use of gloves during sample collection, not sharing of needles, proper disposing of syringe.

\section{Conclusion}

The overall general knowledge among the laboratory technicians on $\mathrm{HCV}$ infection was considered to be good and it was similar with the findings from focus group discussions as well. The study findings strongly support to take appropriate preventive measure against $\mathrm{HCV}$ infection. Adequate program on updating knowledge, strict use of gloves and sterile instrument during sample collection procedure will be helpful in minimizing transmission of $\mathrm{HCV}$ infection.

Conflict of interest: We have no conflict of interest

\section{References}

1. Albert Lasker Award for Clinical Medical Research, The Lasker Foundation. Available from:http://www.laskerfoundation.org/awards/ library/2000/cit.html. Accessed 20 February 2008.

2. Fung J, Lai C-L, Hung I, et al. (2008). "Chronic Hepatitis C virus genotype 6 infection: Response to pegylated interferon and ribavirin". J Infect Dis 198 (6): 808-12.3. World Health Organization. Hepatitis C. Weekly Epidemiological Record, 1997, 72: 65-69.

4. Choo Q, Kuo G, Weiner A, et al. "Isolation of a cDNA clone derived from a blood-borne nonA, non-B viral hepatitis genome."Science 244(4902): 359-62. 
5. World Health Organization. Hepatitis C. Weekly Epidemiological Record 1997; 72: 65-69. Available from: http://www.who.int/inffs/en/fact164.html.

6. Ruiz J, Molitor F, Plagenhoef J. Trends in Hepatitis C and HIV infection among inmates entering prisons in California, 1994 versus 1999. AIDS 2002; 16(16): 2236-8

7. Campbell J, Hagan $\mathrm{H}$, Latka $\mathrm{M}$, et al. editors. High prevalence of alcohol use among hepatitis $\mathrm{C}$ virus antibody positive injection' drug users in three US cities. Drug Alcohol Depend 2006; 81(3): 259-65.

8. Mc Govern B, Wurcel A, Kim A, et al. editors. Acute hepatitis $\mathrm{C}$ virus infection in incarcerated injection drug users. Clin Infect Dis 2006; 42(12): $1663-70$.

9. Khan M, Husain M, Yano M, et al. Comparison of seroepidemiology of hepatitis $\mathrm{C}$ in blood donors between Bangladesh and Japan. Gastroenterol Jpn 1993; 28: 28-31.

10. Akbar SMF, Hossain M, Hossain MF, et al. Seroepidemiology of hepatitis viruses of chronic liver diseases in Bangladesh: high prevalence of HCV among blood donors and healthy persons. Hepatol Research 1997; 7: 113-20.
11. Shirin T, Ahmed T, Iqbal A, et al. Prevalence and risk factors of hepatitis B virus, Hepatitis C virus, and human immunodeficiency virus infections among drug addicts in Bangladesh. $J$ Health Popul Nutr 2000; 18: 145-50.

12. Calver J. Occupational Health Services. Am J Infect Control 1997; 25: 363-5.

13. HepatitisC: Thesilentkiller. Availablefrom: IJRL: http: //www.infoplease.comlcig/ dangerous-diseases-epidemicsfhepatitis-c-silent killer. Accessed on 13 Oct 2008.

14. Prasad L. Knowledge And Risk Behavior On Hepatitis C Infection Among The Laboratory Health Workers In Kathmundu Nepal. Department of public Health northern University, Bangladesh. April 2009.

15. Hussain S, Patrick N, Shams R, et al. Hepatitis $\mathrm{B}$ and $\mathrm{C}$ Prevalence and Prevention,Awareness among Health Care Workers in a Tertiary Care Hospital. International Journal of Pathology 2010; 8(1): 16-21.

16. Gurubacharya DL, KC Mathura, Karki DB. Knowledge, attitude and practices among health care workers on needle-stick injuries. Available from:LJRL:http://www.kurnj.corn.np/site/ index. Accessed on Oct 172008. 